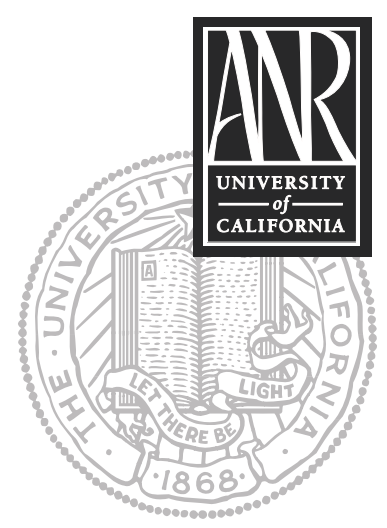

UNIVERSITY OF CALIFORNIA

Division of Agriculture and Natural Resources http://anrcatalog.ucdavis.edu

\title{
NUTRITION AND HEALTH INFO SHEET Iron and Iron Deficiency Anemia
}

ANDREA BERSAMIN, Post Doctoral Scholar, School of Medicine, Stanford University; KARRIE HENEMAN, Assistant Project Scientist, Department of Nutrition, University of California, Davis; CRISTY HATHAWAY, Research Assistant; Department of Nutrition, University of California, Davis; SHERI ZIDENBERG-CHERR, UC Cooperative Extension Nutrition Science Specialist, Department of Nutrition, University of California, Davis

\section{Why is iron important?}

Iron is a major component of hemoglobin, a substance that carries oxygen to all parts of the body. Iron also plays a critical role in overall cell function, assisting in oxygen utilization, enzymatic systems, and especially neural development. Thus, all body functions are affected by iron deficiency in general and not only by anemia, which appears late in the process of tissue iron deficits. Hematocrit is a test used to measure the number and size of red blood cells, and results are used to diagnose iron deficiency anemia.

\section{What is iron deficiency?}

Iron is found in the body in two forms, as functional iron (serving a metabolic function) and as storage iron. When people have depleted their stores of iron, they are said to be "iron deficient." When the depletion progresses, the hemoglobin concentration in red blood cells falls below the normal range (the 95 percentile for age). At this point, a person is classified as having anemia. Iron deficiency can exist with or without anemia. ${ }^{1,2}$

\section{What are the consequences of iron deficiency?}

The continuum from iron deficiency to iron deficiency anemia has a host of associated consequences, depending on the severity of iron depletion.

Iron deficiency without anemia has few discernable outcomes but it has been shown to reduce work capacity, particularly in regards to endurance. As iron deficiency progresses to anemia, further consequences become more evident, including changes in behavior and intellectual performance, reduced resistance to infection, increased susceptibility to lead poisoning, loss of appetite, tachycardia, and cardiomegaly.

In young children, prolonged iron deficiency anemia has been associated with motor and cognitive deficits and an inability to concentrate. These symptoms are not always reversed with iron supplementation.

In pregnant women, iron deficiency anemia has been associated with adverse effects for both the mother and fetus, including increased perinatal complications, premature delivery, and low birth weight.

\section{What other nutritional conditions can cause anemia (low hemoglobin levels)?}

- Deficiencies of other essential nutrients such as vitamins $A, C$, and $B_{12}$, folic acid, thiamine, and pyridoxine can also cause anemia by interfering with the formation of hemoglobin.

- A copper deficiency could result in anemia, as adequate copper intake is needed for the transport of iron throughout the body. 
- A riboflavin deficiency, seen most frequently in alcoholics, can contribute to poor iron absorption and utilization, and to a decrease in the oxygen-carrying capacity of red blood cells.

- A vitamin E deficiency can impair the integrity of the red blood cell membrane and lead to hemolytic anemia.

\section{What causes iron deficiency?}

- The diet may be low in iron or it may contain iron in forms that are poorly absorbed.

- Body iron stores may be low as a result of rapid growth (this is especially common in young children) or as a result of blood loss. Women are particularly at risk for iron deficiency due to the blood losses associated with pregnancy, childbirth, and menstruation.

- Infants (newborns up to 12 months) who have been fed cow's milk are more likely to develop iron deficiency than their breastfed counterparts, due to several factors. Iron deficiency may result from intestinal blood loss caused by a reaction to cow's milk. A deficiency can also be attributed to the lower absorption rate of iron from cow's milk as compared with breast milk (10 percent versus 50 percent). Furthermore, breastfed infants have been shown to have larger iron stores than non-breastfed infants..$^{1,2}$

- High intakes of calcium can inhibit iron absorption if both are present in the same meal. Separating foods high in calcium from those high in iron during meals and snacks may prevent some of this calcium-induced inhibition. In certain studies, though not in all, calcium from both supplements and dairy products inhibited the absorption of nonheme iron when these items were added to meals. (Nonheme iron is the form of dietary iron that the body absorbs less easily.) A balanced and varied diet should overcome the effects of any such inhibition. ${ }^{1}$

\section{How much iron is needed each day?}

Several factors influence the body's iron requirement, including iron intake, stores, and loss. ${ }^{3}$ The Recommended Dietary Allowance (RDA) for iron for all age groups of men and postmenopausal women is $8 \mathrm{mg} / \mathrm{day}$, and for premenopausal women it is $18 \mathrm{mg} /$ day. The difference in values between the two groups is primarily related to the need to replace iron losses due to menstruation. Pregnant women require even more iron: $27 \mathrm{mg} /$ day. $^{2}$ For children of both sexes between the ages of 6 months and 11 years, the RDA is $11 \mathrm{mg} /$ day.

The typical Western mixed diet can provide only about 6 to $7 \mathrm{mg}$ of iron per 1,000 calories. Because most men consume in excess of 2,000 calories per day, it is not very difficult for them to meet their RDA through diet. Women (and younger children), on the other hand, generally eat less meat and fewer calories, and thus should be particularly careful to include iron-rich foods in their daily diet.

\section{In what forms is iron found in the diet?}

Dietary iron is found in two forms: heme and nonheme iron. Heme iron, found in red meats, fish, and poultry, is readily absorbed regardless of the other components in a meal. By contrast, nonheme iron is found in both plant and animal sources, is absorbed to a much smaller degree, and is frequently affected by other food constituents. 


\section{What are good sources of nonheme iron?}

Nonheme iron accounts for more than 85 percent of the iron in the diet. Good sources of it include dried apricots, oatmeal, spinach, pine nuts, beans, and iron-fortified breads and cereals. Although the quantity of iron absorbed from breads and cereals may be low, these sources are eaten in large enough amounts that the iron found in them can be an important portion of daily intake. Other sources of iron are foods that have been cooked in iron cookware.

\section{What affects the absorption of dietary iron?}

The amount of iron absorbed by the body depends on its form in food, the body's iron stores, and other factors. Iron absorption can vary significantly from person to person and also from meal to meal: coffee or tea taken with a meal can reduce absorption by as much as 50 percent. Individuals can absorb anywhere from less than 1 percent to more than 50 percent of the iron in their diet.

Dietary factors that can reduce nonheme iron absorption include phytates (found in grains, legumes, and rice); soy protein and soy fiber; oxalates (found in spinach); and tannic acid (found in teas and coffee). Calcium (found in dairy products) can reduce the absorption of both nonheme and heme iron. ${ }^{2}$

In order to maximize iron uptake, foods high in nonheme iron should be eaten at the same time as those that are a good source of vitamin $C$, such as orange juice, tomatoes, bell peppers, strawberries, cantaloupe, or broccoli. Absorption of nonheme iron can also be enhanced by the presence of heme iron. ${ }^{2}$ A stew made with beans, tomatoes, and a small amount of meat, for example, would maximize the iron potential of both the meat and the beans.

\section{Who is most at risk for iron deficiency?}

\section{Young children}

Very young children are at particular risk for iron-deficiency anemia due to their rapid growth rate. In addition, children's diets may rely heavily on milk products, which, while providing an excellent source of calcium, are not good sources of iron and can decrease iron absorption from other foods.

\section{Pregnant Women}

Because adequate intakes of iron are crucial for both the woman and her fetus, the RDA for iron during pregnancy is $27 \mathrm{mg}$ /day. Iron is needed during pregnancy to replace iron lost in the course of daily activities, to allow for the needed expansion of the red blood cell mass, to provide iron to the placenta and fetal bone tissues, and to replace iron lost during delivery.

\section{Vegetarians}

Iron deficiency is seen more frequently in those children whose diets do not include meats (even though they may consume eggs or dairy products) as compared to omnivorous children. Care should be taken to ensure that foods containing available iron are included in the diet.

\section{Women of childbearing age}

Only 25 percent of this group meet the RDA for iron. ${ }^{2}$ Small iron stores coupled with loss of iron due to menstruation place women of childbearing age at risk. The additional requirements during pregnancy make it critical for a woman to ensure sufficient iron stores prior to the pregnancy. 


\section{Women with high menstrual losses (menorrhagia)}

Menorrhagia (greater than $80 \mathrm{ml}$ per month) occurs in about 10 percent of women and frequently leads to iron-deficiency anemia. Women with menorrhagia are characteristically unaware of their greater-than-normal menstrual blood loss; for this reason, anemia screening at the time of routine health examinations is worthwhile.

\section{Who should be screened for iron deficiency?}

Each of the high-risk groups (young children, pregnant women, vegetarians, and women of childbearing age, especially those with high menstrual losses) should be screened at the time of routine health examinations.

\section{How is iron deficiency anemia defined clinically?}

The following table gives figures for iron deficiency anemia:1,3

\begin{tabular}{|l|l|l|}
\hline Children & $\begin{array}{c}\text { Hemoglobin } \\
(\mathbf{g} / \mathbf{d} \mathbf{l})\end{array}$ & $\begin{array}{c}\text { Hematocrit } \\
\mathbf{( \% )}\end{array}$ \\
\hline 1 to $<2$ years & 11.0 & 32.9 \\
\hline 2 to $<5$ years & 11.2 & 33.0 \\
\hline 5 to $<8$ years & 11.5 & 34.5 \\
\hline 8 to $<12$ years & 11.9 & 35.4 \\
\hline Males & & \\
\hline 12 to $<15$ years & 12.5 & 37.3 \\
\hline 15 to $<18$ years & 13.3 & 39.7 \\
\hline$\geq 18$ years & 13.5 & 39.9 \\
\hline Females & & \\
\hline 12 to $<15$ years & 11.8 & 35.7 \\
\hline 15 to $<18$ years & 12.0 & 35.9 \\
\hline$\geq 18$ years & 12.0 & 35.7 \\
\hline Pregnancy & & \\
\hline 1st trimester & 11.0 & 33.0 \\
\hline 2nd trimester & 10.5 & 32.0 \\
\hline 3rd trimester & 11.0 & 33.0 \\
\hline
\end{tabular}

Note: Low hemoglobin or hematocrit lists do not necessarily mean iron deficiency anemia, so this condition should be confirmed with a test for serum ferritin concentrations or a mean corpuscular volume (MCV) or an erythrocyte protoporphyrin (EP) test to distinguish iron deficiency from other forms of anemia.

\section{When are iron supplements warranted?}

To prevent iron deficiency during pregnancy, the routine consumption of $30 \mathrm{mg}$ of ferrous iron per day is recommended, beginning at about week 12 of gestation, in conjunction with a well-balanced diet that contains enhancers of iron absorption. If diagnosed with iron deficiency anemia, a pregnant woman should be treated with 60 to $120 \mathrm{mg}$ of ferrous iron daily until the hemoglobin concentration becomes normal for the stage of gestation; at this point the dosage can be decreased to $30 \mathrm{mg} /$ day. $^{3}$

Iron supplements are generally recommended if a child (after six months of age) is fed a vegetarian diet or one that does not include iron-supplemented formulas or cereals.

The diagnosis of iron deficiency at any point in the life cycle warrants an examination of the diet and possible iron supplementation. Common forms of supplementation include ferrous sulfate (20 percent iron by weight), ferrous gluconate
nt). The recommended dose depends on ( 12 percent) and ferrous fumarate ( 32 percent). The recommended dose depends on
the patient's age and the severity of the deficiency. If there are gastrointestinal symptoms with a given dose, the dose can be divided or decreased. However, one dose per day has the advantage of favoring compliance. Older children can be given iron divided into 2 daily doses, ideally on an empty stomach, with water or fruit juice (not milk) to enhance absorption. Currently, there is interest in the possibility that iron supplementation once a week might be as effective for improving iron status as daily administration. This is currently being studied in pregnant women. 


\section{Can too much iron be toxic to the body?}

Despite the high prevalence of iron deficiency, excessive iron intake is also a source of adverse affects. In fact, iron overdose is the leading cause of poisoning deaths in children under 6 years of age. ${ }^{2}$

Adverse affects are usually seen with intakes between 20 and $60 \mathrm{mg} / \mathrm{kg}$, and, depending on the quantity of iron ingested, the cardiovascular system, central nervous system, kidneys, liver, and hematologic system can be affected.

\section{REFERENCES}

1. Center for Disease Control and Prevention (CDC). 1998. Recommendations to prevent and control iron deficiency in the United States. Atlanta: Morbidity and Mortality Weekly Report Series. CDC Web site, ftp://ftp.cdc.gov/pub/ Publications/mmwr/rr/rr4703.pdf.

2. Standing Committee on the Scientific Evaluation of Dietary Reference Intakes. 2001. Dietary reference intakes for vitamin A, vitamin K, arsenic, boron, chromium, copper, iodine, iron, manganese, molybdenum, nickel, silicon, vanadium, and zinc: A report of the Panel on Micronutrients. Washington, DC: National Academy Press.

3. Institute of Medicine (U.S.). Subcommittee on Nutritional Status and Weight Gain during Pregnancy. 1990. Nutrition during pregnancy. Washington, DC: National Academy Press.

\section{METRIC CONVERSIONS}

\begin{tabular}{|l|c|c|l|}
\hline English & $\begin{array}{c}\text { Conversion factor for } \\
\text { English to metric }\end{array}$ & $\begin{array}{c}\text { Conversion factor for } \\
\text { metric to English }\end{array}$ & Metric \\
\hline grain & 64.80 & 0.015 & milligram (mg) \\
\hline fluid ounce (fl oz) & 29.57 & 0.034 & milliliter (ml) \\
\hline fluid ounce (fl oz) & 2.96 & 0.0034 & deciliter (d) \\
\hline ounce (oz) & 28.35 & 0.035 & gram (g) \\
\hline
\end{tabular}

\section{FOR FURTHER INFORMATION}

To order or obtain ANR publications and other products, visit the ANR Communication Services online catalog at http://anrcatalog.ucdavis.edu. You can also place orders by mail, phone, or FAX, or request a printed catalog of our products from

University of California

Agriculture and Natural Resources

Communication Services

6701 San Pablo Avenue, 2nd Floor

Oakland, California 94608-1239

Telephone: (800) 994-8849 or (510) 642-2431

FAX: (510) 643-5470

E-mail inquiries: danrcs@ucdavis.edu

An electronic version of this publication is available on the ANR Communication Services Web site at http://anrcatalog.ucdavis.edu.

This publication has been anonymously peer reviewed for technical accuracy by University of California scientists and other qualified professionals. This review process was managed by the ANR Associate Editor for Food and Nutrition.

Publication 8141

ISBN-13: 978-1-60107-498-0 
(C) 2008 The Regents of the University of California

Division of Agriculture and Natural Resources

All rights reserved.

No part of this publication may be reproduced, stored in a retrieval system, or transmitted, in any form or by any means, electronic, mechanical, photocopying, recording, or otherwise, without the written permission of the publisher and the authors.

The University of California prohibits discrimination or harassment of any person on the basis of race, color, national origin, religion, sex, gender identity, pregnancy (including childbirth, and medical conditions related to pregnancy or childbirth), physical or mental disability, medical condition (cancer-related or genetic characteristics), ancestry, marital status, age, sexual orientation, citizenship, or status as a covered veteran (covered veterans are special disabled veterans, recently separated veterans, Vietnam era veterans, or any other veterans who served on active duty during a war or in a campaign or expedition for which a campaign badge has been authorized) in any of its programs or activities. University policy is intended to be consistent with the provisions of applicable State and Federal laws.

Inquiries regarding the University's nondiscrimination policies may be directed to the Affirmative Action/Staff Personnel Services Director, University of California, Agriculture and Natural Resources, 1111 Franklin Street, 6 ${ }^{\text {th }}$ Floor, Oakland, CA 94607-5201, (510) 987-0096. For information about ordering this publication, telephone 1-800-994-8849.

pr-1/08-LR/CM 